\title{
ASSESSMENT OF THE NETWORK INTERACTION SYNERGISTIC EFFECT ACCORDING TO THE ORGANIZATION LIFE CYCLE
}

\author{
Alona Hrebennikova \\ National University of Life and Environmental Sciences of Ukraine, Kyiv, Ukraine \\ Liudmyla Artemchuk \\ National University of Life and Environmental Sciences of Ukraine, Kyiv, Ukraine \\ Vitalii Nahornyi \\ National University of Life and Environmental Sciences of Ukraine, Kyiv, Ukraine \\ Nadiia Daliak \\ Ivano-Frankivsk National Technical Oil and Gas University, Ivano-Frankivsk, Ukraine \\ Olha Ruban \\ National University of Life and Environmental Sciences of Ukraine, Kyiv, Ukraine
}

\begin{abstract}
The purpose of this article is to substantiate econometrically the peculiarities of achieving a synergistic effect and sources of economies of scale for participants in entrepreneurial networks, i.e. industrial enterprises in Ukraine. Regression analysis was used to identify sources of economies of scale of production, a change in which affects the efficiency of enterprises. The features of the manifestation of the effect of economies of scale for 106 network and non-network enterprises was determined using the elasticity coefficient, taking into account the organizational life cycle of the development. It was revealed that, despite the ephemeral nature of the economies of scale, network enterprises are characterized by their longer nature as a component of the synergistic effect of production activities and a decrease in costs, regardless of the development cycle of the organization. The results obtained can be useful as a basis for strategic planning in business integration.
\end{abstract}

Keywords: entrepreneurial networks, network enterprises, economies of scale, synergistic effect, enterprise, organization life cycle

DOI: http://dx.doi.org/10.15549/jeecar.v8i3.754

\section{INTRODUCTION}

According to the latest data from the Ease of Doing Business Index for 2013-2020, Ukraine has seen a significant improvement in the conditions for doing and operating a business over the past seven years, as evidenced by the improvement of Ukraine's positions from 137th place in the ranking in 2013 to 64th in 2020 out of 190 
countries (World Bank Group, 2021). These good results are due to the simplification of the country's taxation and administration system. Providing charitable conditions also has had a direct positive impact on the development of entrepreneurship in Ukraine. The vast majority of Ukrainian companies in the entrepreneurial sector of the economy are small and mediumsized enterprises (SMEs) (The Commercial Code of Ukraine, 2021). As of 2020, SMEs accounted for 99.04\% of all enterprises in the country's business sector, however SMEs provide only about $55 \%$ of the country's GDP and account for about $16 \%$ of GDP as of early 2021. The percentage of SMEs in Ukraine is almost twice the percentage of SMEs in Europe, yet their effectiveness is 10 times lower (Problems of small and middle business: an expert's glance, 2020).

The active development of entrepreneurship in Ukraine, along with the improvement of the business climate in the country, has been accompanied by tougher competition, provoked by the rapid development and distribution of high-tech products and complex solutions in the modern economy, indicative of processes of rapid technological improvement. The desire for survival through development on the part of economic entities in Ukraine at the present stage began to manifest itself in the creation of new forms of doing business, such as entrepreneurial networks (Zadorozhna, 2014). Business formation and development through the creation of integrated structures (entrepreneurial networks) is a new approach to increase competitiveness in a globalized business (Dykan et al., 2021). Entrepreneurial networks have grown out of an urgent need to search for and realize competitive advantages, pursue various business directions, and find ways to improve the effective work of organizations, which have determined the feasibility of a wide range of synergistic effects, the competent disclosure and management of which can qualitatively improve organization efficiency as a whole. Thus, many organizations and enterprises have found a way to diversify their activities. In contrast, others have found a solution to "the problem" through mergers and acquisitions and business networks, as well as the competent use of economies of scale based on strategic business units. True, everything is not always so unambiguous, and when the individual elements are summed up, synergy is not always manifested. Also, synergy is not always positive; it can also be negative, causing quite negative consequences (Schmidt, Makadok \& Keil, 2016). Therefore, it can be argued that to obtain a positive synergistic effect, one-directional actions of each of the partners of the entrepreneurial network are required (Feizabadi \& Alibakhshi, 2021). The fundamental issue in the process of managing the synergy effect is that, unlike physical systems within the organizational system, there are no approaches in organization theory to gain an objective assessment of the level of internal synergy (Feix, 2020). This circumstance, which runs counter to the constant need to solve the practical problems of the management of a modern organization, forces many scholars to conduct active research to develop such assessments. Therefore, our study aims to determine the features of economies of scale in the context of a business network using the example of Ukrainian industrial enterprises and assessing the priority sources of synergistic effects. Furthermore, a comparative assessment of the characteristics of the scale effect of network and non-network enterprises is made, taking into account the peculiarities of their development.

\section{LITERATURE REVIEW}

The effectiveness of the development of entrepreneurial networks in economic science has been studied using a systems approach, which is primarily due to the emergence of a synergistic effect in integrating economic activity (Schmidt, Makadok \& Keil, 2016). A synergistic effect means an increase in the level of efficiency of innovation due to business integration and the merger of business partners due to the manifestation of a synergy effect (Kruja-Demneri, 2020). The source of synergy is the pooling of resources. In this case, a positive and negative effect can occur as a result of:

(a)economies of scale, when an increase in production volumes leads to a reduction in conditionally fixed costs per unit of product sold and an increase in profitability. Or when an increase in financing volume creates opportunities for the acquisition of new equipment with a higher return on assets, which saves on labor costs 
(Rodríguez-Villalobos \& García-Martínez, 2018); and

(b)the effect of network interaction, when the organization network form, in addition to pooling resources, creates additional benefits associated with the development of integration (Kruja-Demneri, 2020).

In many studies (Andriuškevičius \& Štreimikienè, 2021; Gupta, Mishra \& Tripathy, 2021) economies of scale are seen as part of the synergistic effect. But such an effect can arise with any expansion of the scale of activity, regardless of whether the enterprise is a member of a business network or operates without participation in any association. Economies of scale arise as a result of large-scale operations and are based on the law of reducing total costs with increasing production volumes and on a complete use of capacities (Trunina \& Ashourizadeh, 2021).

In organization theory, the synergistic effect is synonymous with the effect of integration and cooperation of activities. This is a systemic effect that characterizes the system by the volume of properties that allow one to exceed the sum and quality parameters of the properties of the individual components of the system. Because a business network presupposes the variability of the combination of economic and innovative activity areas, various levels and types of the synergetic potential of the organization are formed - from very low to very high and from positive to negative. The potential of a network partner and the total potential of an integrated organization depends on each employee and their placement, technological equipment, professionalism of managers, etc. (Kim, 2014). The most complete and timely assessment of the level and consequences of the synergistic effect allows companies to support competitiveness or identify the key factors of intra-organizational synergy (Schmidt, Makadok \& Keil, 2016). Conversely, ineffective or the lack of planning for business integration is one of the main reasons for the lack of synergies or the manifestation of risks in business. Consequently, based on the foregoing, it can be assumed that for network enterprises, the economies of scale will also have their own optimal time frames and be characterized by ephemerality (hypothesis (H1)).
In the scientific literature, research results are widely presented regarding the dependence of the life cycle of a product with the phases of the organization life and financial cycle (Zarte, Pechmann \& Nunes, 2019; Chen \& Huang, 2019). This cycle begins with the implementation of an investment project. The organization then reaches the profitability threshold (zero profit), accumulates a margin of financial strength, and implements the next investment project. Therefore, it would be logical to assume that organizations can resonate with the life cycles of projects being implemented in the event of a coincidence of phases, which can cause a synergistic effect in the course of their activities. Resonance, in this case, can manifest itself in a change in the indicators of the effectiveness of the organization's economic activity (KrujaDemneri, 2020) or changing the qualitative parameters of its activities (Shi et al., 2018). Consequently, each stage of the life cycle is distinguished by the organization's need for funding, innovative research, conquering new sales markets, etc. In turn, the synergistic effect creates opportunities to meet these organizational needs. (Kruja-Demneri, 2020). Based on this, it can be assumed that, depending on the stage of the life cycle, the factors contributing to the emergence and manifestation of a synergistic effect and their influence on the efficiency of the organization's functioning (hypothesis (H2)) will differ. Furthermore, based on this, it can be assumed that the possibility of obtaining a synergistic effect, namely, economies of scale from network interaction for an enterprise, depends on the stage of its life cycle (hypothesis $(H 3)$ ).

An increase in production volumes and the involvement of additional financial capital for its expansion in the future and, up to a certain point, the emergence of accompanying factors (labor and management specialization) (RodríguezVillalobos \& García-Martínez, 2018), increases the efficiency of attracted capital (Akerlof \& Holden, 2019) and the innovativeness of production (Rajagopal, 2014), etc., thus ensuring a decrease in the level of average total costs (Rodríguez-Villalobos \& García-Martínez, 2018). Consequently, due to these factors, the expansion of production allows an increase in the return on the resources used and reduces the costs per unit of production. But it should be 
noted that as the company grows, the need to integrate various aspects of its diverse activities arises. As a result, the decision-making process becomes more complex, and the administrative burden disproportionately increases. As a result, there is a need to delegate authority to lowerlevel managers whose competence may not meet the necessary requirements. An increase in informalities accompanies the increase in economies of scale. Bureaucratic procedures are formed that make the management hierarchy of large firms sluggish and cumbersome, which leads to a gradual decrease in efficiency (Canbäck, Samouel \& Price, 2006). But within the framework of the integration of economic activity, combining the efforts of entrepreneurs, governing bodies and business entities provides significant advantages in the competitive struggle and rationalization of production and market processes. (Dykan et al., 2021).

Due to these factors in the process of business integration, such a set of organizations is formed which is coordinated only by market mechanisms, as opposed to the methods of command-and-control management. Entrepreneurial networks are formed based on the principles of adaptability and self-evolution. They have a fundamentally different mechanism of external competitiveness within the organization, which is adequate to external market competitiveness in terms of its essential characteristics (Trunina \& Ashourizadeh, 2021; Megits, Neskorodieva \& Schuster, 2020). Due to the decentralized organization model, market competitiveness is achieved by all participants in network links without losses and the weakening of each lowest level of the network. Thus, the value of a high level of management in a business network lies in creating a mechanism for the distribution of competitiveness, and the formation and maintenance of a fixed system of rules of behavior within the organization of all actors. In turn, the high potential of competitiveness in network structures creates the basis for the effective implementation of all the main characteristics of an organization capable of self-development and constant evolution (Cygler \& Sroka, 2014). Based on the foregoing, it can be assumed that within the framework of the entrepreneurial network (integrated business), the scale effect for network partners is of a longer-term nature since it is determined by better management within the organization (hypothesis (H4)).

\section{METHODOLOGY}

The sample used in this study was formed based on data from two samples of enterprises characterizing the economic activity of enterprises of the manufacturing industry in Ukraine Sample 1 consists of participants in such entrepreneurial networks as: Association "Ukrmashbud» (8 enterprises); The State Concern «Ukroboronprom» (41); DCH (2); UPEC Industrial Group (3); " Ukrmetalurgprom» (6); and Association "Ukrlegprom» (10). For sample 2, data from 36 Ukrainian machine-building, metallurgical and light industry enterprises which are not members of network associations was used. The values of the indicators covered the years 2015-2020. For enterprises in the 1st sample, which became part of the entrepreneurial network after 2015, data from the moment the network partnership began was used.

To simulate a synergistic effect based on economies of scale and to test the hypotheses, the multivariate regression analysis method in the EViews 10 program was used.

The indicator of the profitability of the company's assets (Rent), calculated based on the company's net profit, was used as a dependent variable. This indicator is the most generalized indicator of the efficiency of the enterprise (Neskorodeva \& Pustovgar, 2015).

The explanatory variables are based on the types and sources of economies of scale (Growth rate) (Kozan \& Akdeniz, 2014; Trunina \& Ashourizadeh, 2021):

1) Retained Earnings (GR_Prof) - an indicator of the availability of self-financing sources (except for data with a negative value of retained earnings);

2) Attracting Capital (GR_Cap) - an indicator of the availability of financial resources: owned and attracted, respectively;

3) Net Book Value of Fixed Assets (at residual value) and Inventories ( $G R_{\_}$Prod) - a resource availability indicator;

4) Average Number of Employees (GR_Staff) a labor force availability indicator; 
5) Short- and Long-term Investments ( $G R$ $I n V)$ - an investment potential indicator;

6) Distribution Costs (GR_Mark) - a marketing potential indicator;

7) Intangible Assets (GR_Intan) - an indicator of the availability of intangible resources (copyright and related rights, the right to use natural resources, industrial property, trademarks).

These indicators reflect the resources due to which it is possible to obtain a positive synergistic effect. No indicator would reflect the innovative potential in the specified list of indicators due to the lack of such data for Ukrainian enterprises. For industrial enterprises, innovation mainly aims to update production assets (Neskorodeva \& Pustovgar, 2015); the dynamics of the value are reflected through the indicator GR_Prod.

When constructing the models, the growth rates of indicators in a dimensionless value were used. In addition, extreme values detected using the Dixon test were excluded to improve the simulation accuracy.

To determine the phase of the life cycle of enterprises, the survey method was used (Determination of the Organizational Life Cycle Stages, 2021). The survey was conducted during March-May 2021 and was attended by 40-50 experts - representatives from each enterprise included in the study sample. In the course of the questionnaire survey, the respondents were asked to express their agreement (on a "Yes" I "No" scale) with the statements of the questionnaire regarding the company they represent. These statements characterized each stage of the enterprise life cycle: formation, growth, maturity, decline. To determine the enterprise's life cycle stage, the percentage of positive answers ("Yes") was calculated for each group of questions in the questionnaire. The highest level of positive answers was characteristic of the corresponding stage of the enterprise's development.

Sufficient representation of experts from each enterprise (Hsu-Ming, Kung-Jen \& Ting-Yi, 2021) indicates the representativeness of the survey results. Representativeness was evidenced by the level of agreement of experts regarding the stage of the life cycle of the studied enterprises: $100 \%$.

\section{RESULTS}

\section{Empirical Assessment of the Scale Effects of Network Partners}

For a sample of enterprises that are members of entrepreneurial networks, the Chow test allowed us to identify the different nature of the interdependencies between the dependent and independent variables following the stages of the enterprise life cycle, which was taken into account when constructing our models (Table 1 ). The calculated rejection probability of the hypothesis of structural breaks (Chow Test Prob) does not exceed 0.05 and is in the range of 0.01 0.04 .

According to the constructed models, the number of observations is 8.5-29.2 times greater than the number of independent variables, which indicates the sufficiency of the sample (Jenkins \& Quintana-Ascencio, 2020). Each subsample of an enterprise included enterprises of different sizes, industries, and geographic locations. At the same time, the homogeneity of the sample is confirmed by the Student's criterion and other indicators of the adequacy of the models. The excess of the empirical values of $t$-Statistic in modulus is given in Table 1 . Values above the critical 1.97-2.02 at a significance level of $p=0.05$ indicates the statistical significance of the independent variables of the models. Confirmation of the statistical significance of the models is also evidenced by:

1) the excess of the empirical values of the $F$-statistic (19.53-44.17) over the critical values 2.16-2.31 at a significance level of $p=$ 0.05 ;

2) a lack of heteroscedasticity in the model (Heteroskedasticity Test: Prob $>0.05$ );

3 ) the absence of multicollinearity in the model (paired correlation coefficients between independent variables do not exceed | $0.21 \mid$, which indicates a weak relationship between them);

4) the normal distribution of the residuals of the models (Normality Test: Prob>0.05);

5 ) the correct choice of the regression model modification (Ramsey Test: Prob>0.05). 
Table 1: Parameters of regression models for estimating economies of scale for network partners

\begin{tabular}{|c|c|c|c|c|c|c|}
\hline \multirow[b]{2}{*}{$\begin{array}{l}\text { Independent } \\
\text { variables }\end{array}$} & \multicolumn{4}{|c|}{ Explanatory variables } & \multicolumn{2}{|l|}{ Model adequacy indicators } \\
\hline & $\begin{array}{l}\text { Coefficie } \\
\text { nt }\end{array}$ & $\begin{array}{l}t- \\
\text { Statistic }\end{array}$ & $\begin{array}{l}p- \\
\text { level }\end{array}$ & $\begin{array}{l}\text { Elasticit } \\
\mathrm{y}, \%\end{array}$ & Indicator & Value \\
\hline \multicolumn{7}{|c|}{ Formation stage } \\
\hline \multicolumn{5}{|c|}{ Included observations: 51} & F-statistic & 19.53 \\
\hline \multicolumn{5}{|c|}{ Dependent variable: Rent } & Prob (F-statistic) & 0.00 \\
\hline GR_Prof & 1.30 & 4.31 & 0.00 & \multirow[b]{2}{*}{2.26} & Ramsey Test: Prob & 0.62 \\
\hline GR_Prof & -0.16 & -2.84 & 0.02 & & $\begin{array}{l}\text { Heteroskedasticity } \\
\text { Prob }\end{array}$ & 0.78 \\
\hline GR_Cap & 0.14 & 4.01 & 0.00 & \multirow{2}{*}{1.76} & Normality Test: Prob & 0.63 \\
\hline$G R \_C a p^{2}$ & -0.02 & -2.65 & 0.03 & & & \\
\hline GR_Mark & 0.18 & 3.64 & 0.01 & \multirow{2}{*}{1.62} & & \\
\hline GR_Mark ${ }^{2}$ & -0.02 & -2.62 & 0.03 & & & \\
\hline Intercept & -0.02 & - & - & - & & \\
\hline \multicolumn{7}{|l|}{ Growth stage } \\
\hline \multirow{2}{*}{\multicolumn{5}{|c|}{$\begin{array}{l}\text { Included observations: } 175 \\
\text { Dependent variable: } R e n t\end{array}$}} & F-statistic & 38.50 \\
\hline & & & & & Prob (F-statistic) & 0.00 \\
\hline GR_Prof & 1.40 & 4.29 & 0.00 & \multirow[b]{2}{*}{2.22} & Ramsey Test: Prob & 0.79 \\
\hline$G R \_$Prof & -0.19 & -3.12 & 0.02 & & $\begin{array}{l}\text { Heteroskedasticity } \\
\text { Prob }\end{array}$ & 0.61 \\
\hline GR_Cap & 0.14 & 3.27 & 0.01 & \multirow{2}{*}{1.63} & Normality Test: Prob & 0.69 \\
\hline$G R \_C a p^{2}$ & -0.02 & -2.51 & 0.02 & & & \\
\hline GR_Mark & 0.21 & 3.49 & 0.01 & \multirow{2}{*}{1.76} & & \\
\hline GR_Mark ${ }^{2}$ & -0.03 & -2.59 & 0.02 & & & \\
\hline Intercept & -0.02 & - & - & - & & \\
\hline \multicolumn{7}{|l|}{ Maturity stage } \\
\hline \multirow{2}{*}{\multicolumn{5}{|c|}{$\begin{array}{l}\text { Included observations: } 55 \\
\text { Dependent variable: } \text { Rent }\end{array}$}} & F-statistic & 44.17 \\
\hline & & & & & Prob (F-statistic) & 0.00 \\
\hline GR_Prof & 2.06 & 3.85 & 0.00 & \multirow[b]{2}{*}{2.06} & Ramsey Test: Prob & 0.60 \\
\hline GR_Prof & -0.28 & -2.41 & 0.02 & & $\begin{array}{l}\text { Heteroskedasticity } \\
\text { Prob }\end{array}$ & 0.92 \\
\hline GR_Intan & 0.98 & 2.97 & 0.02 & \multirow{2}{*}{1.16} & Normality Test: Prob & 0.72 \\
\hline$G R \_I n t a n^{2}$ & -0.16 & -2.35 & 0.03 & & & \\
\hline GR_Mark & 0.32 & 3.11 & 0.01 & \multirow{2}{*}{1.64} & & \\
\hline GR_Mark ${ }^{2}$ & -0.05 & -2.17 & 0.04 & & & \\
\hline Intercept & -0.03 & - & - & - & & \\
\hline \multicolumn{7}{|l|}{ Decline stage } \\
\hline \multicolumn{5}{|c|}{ Included observations: 81} & F-statistic & 24.72 \\
\hline \multicolumn{5}{|c|}{ Dependent variable: $R e n t$} & Prob (F-statistic) & 0.00 \\
\hline GR_Intan & 0.96 & 2.95 & 0.02 & \multirow[b]{2}{*}{1.09} & Ramsey Test: Prob & 0.51 \\
\hline$G R \_I n t a n^{2}$ & -0.15 & -2.38 & 0.03 & & $\begin{array}{l}\text { Heteroskedasticity } \\
\text { Prob }\end{array}$ & 0.74 \\
\hline GR_Mark & 0.28 & 3.30 & 0.01 & \multirow{2}{*}{1.36} & Normality Test: Prob & 0.55 \\
\hline GR_Mark ${ }^{2}$ & -0.04 & -2.18 & 0.04 & & & \\
\hline GR_Prod & -0.32 & -3.39 & 0.01 & -0.79 & & \\
\hline GR_Staff & -0.27 & -3.27 & 0.01 & -0.66 & & \\
\hline Intercept & 0.00 & - & - & - & & \\
\hline
\end{tabular}

Source: author's calculations 
Positive values of elasticity indicators for GR_Prof, GR_Cap, GR_Mark, GR_Intan indicate positive economies of scale. The elasticity indicators were calculated relative to the sample mean values of the independent variables.

According to the constructed models, the most significant effect of scale in business networks is provided by an increase in retained earnings. A $1 \%$ growth in retained earnings growth contributes to an increase in efficiency by 2.06 $2.26 \%$ due to the expansion of self-financing sources. The GR_Prof indicator is statistically significant for the stages of formation, growth and maturity. The insignificance of the indicator at the stage of decline is explained by the lack of net profit for most of the enterprise and, accordingly, the lack of self-financing sources.

In addition to the GR_Prof indicator, the sources of positive effect for network enterprises are at the stage of formation and growth $G R \_$Cap and GR_Mark indicators, at the stage of maturity and decline. - GR_Intan, GR_Mark.

The positive effect with an increase in the growth rate of the amount of sales costs (GR_Mark) is provided due to an increase in the efficiency of the management of marketing costs resulting from joint mutually beneficial use of market advantages between the business partners of the network.

At the formation and growth stages, an additional opportunity to raise funds (an increase in the GR_Cap indicator) has a positive effect on the efficiency of enterprises. These opportunities arise due to the concentration of financial resources of the participants in the associations.

A positive synergistic effect also arises with an increase in the value of intangible assets. An increase in GR_Intan by $1 \%$ leads to an increase in efficiency by $1.16 \%$ at the stage of maturity and by $1.12 \%$ at the stage of decline.

For industrial enterprises, increased production is the main source of economies of scale (Kozan \& Akdeniz, 2014). But, as the study results have shown, at the stages of formation, growth and maturity, the influence of the GR_Prod indicator on the profitability of enterprises is insignificant. At the stage of decline, this indicator harms the efficiency of enterprises. An increase in GR_Prod by $1 \%$ leads to a decrease in profitability by $0.32 \%$. For the accumulation of means of production with a high level of depreciation of fixed assets, a reduction in production volumes leads to additional costs, as a result of which the positive effect of savings on conditionally fixed costs is leveled.

An increase in the GR_Staff indicator has a similar effect on the efficiency of enterprises in decline. For example, an increase in this indicator by $1 \%$ leads to a decrease in the profitability indicator by $0.27 \%$. The negative impact of the growth in the number of employees on the efficiency of the enterprise is explained by the low level of production automation at industrial enterprises, a significant proportion of administrative personnel, and a decrease in the productivity of workers in the context of a decrease in production volumes.

Despite the negative impact of GR_Prod and $G R \_$Staff indicators on the efficiency of enterprises at the stage of decline, the aggregate elasticity indicator for these enterprises is positive (1\%).

The positive values of the indicators of the elasticity of profitability of enterprises indicate that regardless of the life cycle stage in conditions of business network, the effect of scale has a positive effect on the efficiency of the functioning of enterprises. This confirms hypothesis $\mathrm{H} 2$.

\section{Comparative assessment of economies of scale} for networked and non-networked enterprises

Similar regression models were built to assess the effect of scale at non-network enterprises (Table 2).

Differences in the values of variables, statistically significant according to the Student's criterion and depending on the industry sector and geographic affiliation, were not found for non-network enterprises. The Chow test, similar to network enterprises, indicates statistically significant differences in the effect of independent variables depending on the stage of the organization's life cycle. The adequacy of the constructed regression models is confirmed by the F-statistic, Ramsey, Heteroskedasticity, and Normality Test indicators, which are interpreted similarly to the sample of network-type enterprises. 
Table 2: Parameters of regression models for assessing the performance of non-network enterprises

\begin{tabular}{|c|c|c|c|c|c|c|}
\hline \multirow[b]{2}{*}{$\begin{array}{l}\text { Independent } \\
\text { variables }\end{array}$} & \multicolumn{4}{|c|}{ Explanatory variables } & \multicolumn{2}{|l|}{ Model adequacy indicators } \\
\hline & Coefficient & $\begin{array}{l}t- \\
\text { Stati } \\
\text { stic }\end{array}$ & $\begin{array}{l}p- \\
\text { level }\end{array}$ & Elasticity, \% & Indicator & Value \\
\hline \multicolumn{7}{|c|}{ Formation stage } \\
\hline \multicolumn{5}{|c|}{ Included observations: 52} & F-statistic & 5.83 \\
\hline \multicolumn{5}{|c|}{ Dependent variable: $R e n t$} & Prob (F-statistic) & 0.02 \\
\hline GR_Prof & 2.03 & 5.11 & 0.00 & \multirow[b]{2}{*}{2.32} & Ramsey Test: Prob & 0.50 \\
\hline$G R \_$Prof & -0.31 & $\begin{array}{l}- \\
3.01\end{array}$ & 0.01 & & $\begin{array}{l}\text { Heteroskedasticity Test: } \\
\text { Prob }\end{array}$ & 0.82 \\
\hline$G R \_C a p$ & 0.26 & 3.28 & 0.00 & \multirow[b]{2}{*}{1.73} & Normality Test: Prob & 0.76 \\
\hline$G R \_C a p^{2}$ & -0.05 & - & 0.04 & & & \\
\hline GR_Mark & 0.43 & 3.01 & 0.01 & \multirow[b]{2}{*}{1.46} & & \\
\hline$G R \_M a r k$ & -0.07 & $-\overline{2}$ & 0.03 & & & \\
\hline Intercept & -0.03 & - & - & - & & \\
\hline \multicolumn{7}{|l|}{ Growth stage } \\
\hline \multirow{2}{*}{\multicolumn{5}{|c|}{$\begin{array}{l}\text { Included observations: } 89 \\
\text { Dependent variable: } R \text { Rent }\end{array}$}} & F-statistic & 19.73 \\
\hline & & & & & Prob (F-statistic) & 0.00 \\
\hline GR_Prof & 2.05 & 5.30 & 0.00 & \multirow[b]{2}{*}{2.29} & Ramsey Test: Prob & 0.91 \\
\hline GR_Prof & -0.33 & $\overline{-}-92$ & 0.02 & & $\begin{array}{l}\text { Heteroskedasticity Test: } \\
\text { Prob }\end{array}$ & 0.83 \\
\hline GR_Cap & 0.24 & 3.15 & 0.00 & \multirow[b]{2}{*}{1.56} & Normality Test: Prob & 0.72 \\
\hline$G R \_C a p^{2}$ & -0.05 & $-\overline{2}$ & 0.04 & & & \\
\hline GR_Mark & 0.47 & 3.10 & 0.00 & \multirow[b]{2}{*}{1.54} & & \\
\hline$G R \_M a r k$ & -0.09 & $\overline{-}-73$ & 0.02 & & & \\
\hline Intercept & -0.03 & - & - & - & & \\
\hline \multicolumn{7}{|l|}{ Maturity stage } \\
\hline \multicolumn{5}{|c|}{ Included observations: 51} & F-statistic & 39.55 \\
\hline \multicolumn{5}{|c|}{ Dependent variable: Rent } & Prob (F-statistic) & 0.00 \\
\hline GR_Prof & 1.90 & 3.24 & 0.00 & \multirow[b]{2}{*}{2.04} & Ramsey Test: Prob & 0.83 \\
\hline$G R \_P r o f$ & -0.30 & $\begin{array}{l}- \\
2.37\end{array}$ & 0.02 & & $\begin{array}{l}\text { Heteroskedasticity Test: } \\
\text { Prob }\end{array}$ & 0.79 \\
\hline GR_Mark & 0.86 & 2.91 & 0.01 & \multirow[b]{2}{*}{1.32} & Normality Test: Prob & 0.61 \\
\hline$G R \_M a r k$ & -0.17 & - & 0.03 & & & \\
\hline Intercept & -0.04 & - & - & - & & \\
\hline \multicolumn{7}{|l|}{ Decline stage } \\
\hline \multicolumn{5}{|c|}{ Included observations: 58} & F-statistic & 20.14 \\
\hline \multicolumn{5}{|c|}{ Dependent variable: $R e n t$} & Prob (F-statistic) & 0.00 \\
\hline GR_Prod & -0.34 & $\overline{3} .62$ & 0.00 & -1.03 & Ramsey Test: Prob & 0.85 \\
\hline$G R \_S t a f f$ & -0.28 & $\overline{-}-\overline{2.95}$ & 0.01 & -0.85 & $\begin{array}{l}\text { Heteroskedasticity Test: } \\
\text { Prob }\end{array}$ & 0.87 \\
\hline Intercept & 0.02 & - & - & - & Normality Test: Prob & 0.62 \\
\hline
\end{tabular}

Source: author's calculations 
The constructed regression models (Tables 1 and 2) made it possible to establish quadratic functions of the dependence of the profitability of enterprises on indicators whose growth creates a positive effect on the scale (GR_Prof, $G R \_C a p, G R \_M a r k, G R \_I n t a n$ for network-type enterprises and GR_Prof, GR_Cap, GR_Mark - for non-network type). This confirms hypothesis $\mathrm{H} 1$ that economies of scale are limited. The growth of resources of enterprises up to a certain point allows for the achievement of a positive effect. A further increase in resources leads to a decrease in their use due to an increase in conditionally fixed costs, a decrease in management efficiency.

Unlike enterprises operating in an integrated business environment, economies of scale are not positive for non-networked enterprises at all life cycle stages. The negative impact at the decline stage is due to the destabilizing effect of the growth of GR_Prod and GR_Staff on the efficiency of enterprises. The growth of these indicators by $1 \%$ in the aggregate leads to a decrease in profitability by $1.88 \%$.

The constructed regression models differ in the list of independent variables that have a statistically significant effect on the efficiency of enterprises, depending on the stage of the life cycle. This confirms hypothesis $\mathrm{H} 3$ that the sources of economies of scale for network and non-network enterprises impact the profitability of enterprises (assessed through elasticity indicators) differ depending on the stage of the life cycle (Fig. 1).

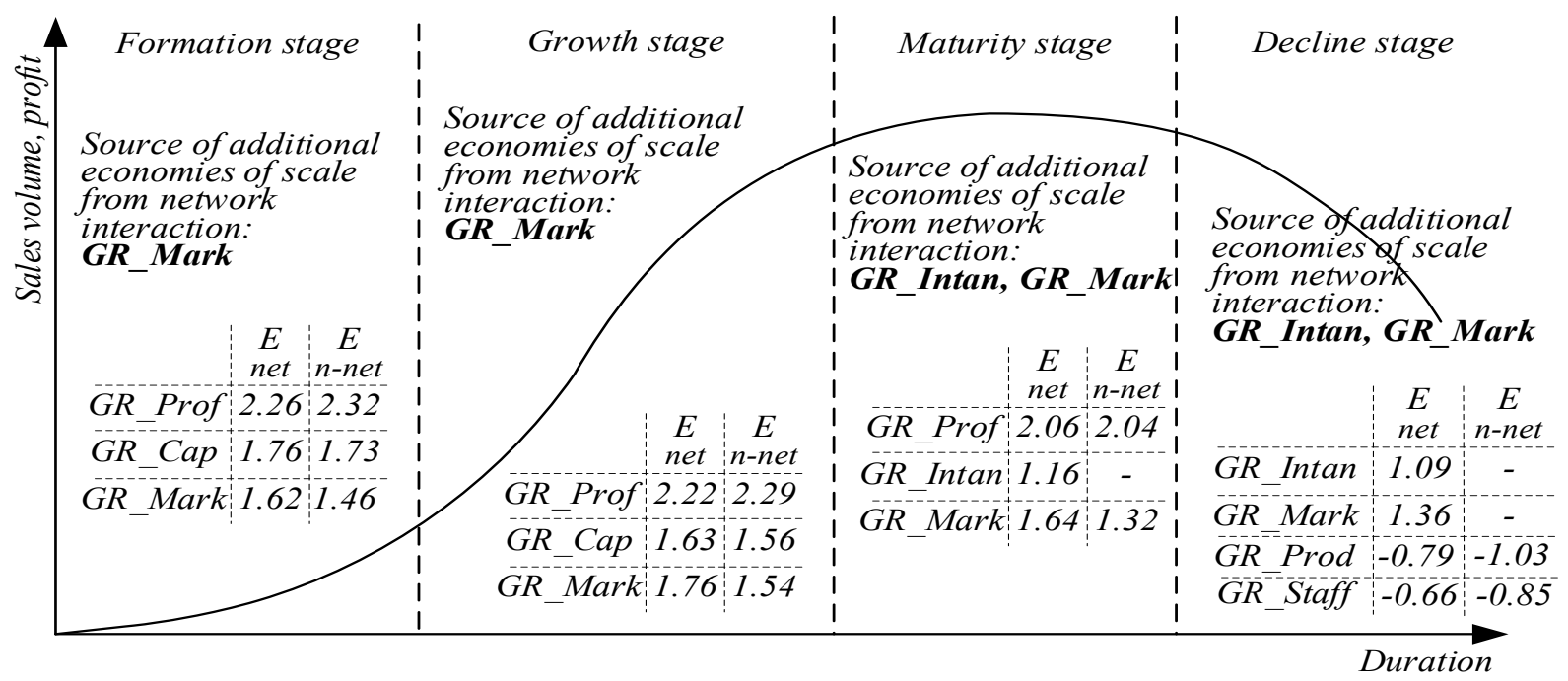

$E_{n e t}$ - values of indicators of elasticity of profitability for indicators-sources of economies of scale for network enterprises;

$E_{n-\text { net }}$ - values of indicators of elasticity of profitability for indicators-sources of economies of scale for non-network enterprises;

Figure 1: Sources of Enterprise-Scale Economies

Source: author's calculations

According to the GR_Prof indicator, for participants in entrepreneurial networks at the maturity stage, the elasticity indicator is $0.98 \%$ higher than for non-network enterprises. For other life cycle stages, the elasticity index is $2.92 \%-3.14 \%$ lower than off-chain. The deviation of the elasticity of profitability of network enterprises from the non-network type according to the GR_Cap indicator (1.48-4.25\%) also does not exceed $5 \%$. Such a deviation, which is less than $5 \%$, cannot be considered significant and creates additional advantages in an enterprise's functioning. 
According to the GR_Mark and GR_Intan indicators, the excess of elasticity indicators for entrepreneurial network partners compared with non-network enterprises is more than $5 \%$. This indicates the presence of an additional synergistic effect of network interaction according to these indicators.
To test hypothesis $\mathrm{H} 4$ according to the constructed models (Tables 1 and 2), the extremum points of the functions were calculated (Table 3). These points show the values of the independent variables at which the value of the profitability indicator is the maximum.

Table 3: Indicators that are sources of economies of scale while maximizing the level of profitability

\begin{tabular}{|l|l|l|l|}
\hline \multirow{2}{*}{$\begin{array}{l}\text { Life cycle } \\
\text { stage }\end{array}$} & \multirow{2}{*}{ Indicator } & Indicator value \\
\cline { 3 - 4 } & & Network enterprises & Non-network enterprises \\
\hline \multirow{4}{*}{ Formation } & GR_Prof & 4.07 & 3.25 \\
\cline { 2 - 4 } & GR_Cap & 3.14 & 2.81 \\
\cline { 2 - 4 } & GR_Mark & 3.93 & 3.07 \\
\hline \multirow{4}{*}{ Growth } & GR_Prof & 3.59 & 3.10 \\
\cline { 2 - 4 } & GR_Cap & 3.01 & 2.65 \\
\cline { 2 - 4 } & GR_Mark & 3.88 & 2.74 \\
\hline \multirow{3}{*}{ Decline } & GR_Prof & 3.66 & 3.18 \\
\cline { 2 - 4 } & GR_Intan & 3.07 & - \\
\cline { 2 - 4 } & GR_Mark & 3.28 & 2.50 \\
\hline & GR_Intan & 3.11 & - \\
\cline { 2 - 4 } & GR_Mark & 3.17 & - \\
\hline
\end{tabular}

Source: author's calculations

The values of indicators-sources of economies of scale at which the profitability of enterprises is maximized are higher for network enterprises. This indicates that these enterprises have more significant potential for economic growth by using positive economies of scale.

\section{DISCUSSION AND CONCLUSION}

The results obtained allowed us to conclude the positive effect of the synergy concept for Ukrainian enterprises that are partners of entrepreneurial networks, which is often used to justify the need to combine companies and analyze the financial viability of this process (Dykan et al., 2021). Within the framework of this study, an econometric approach has been developed, which made it possible to substantiate the fact that, despite the existing properties of the economies of scale as a decrease in the cost of production of goods and services achieved due to an increase in the size of production capacities, its positive character of manifestation is observed for network, and nonnetworked enterprises. Industrial production is one of the most obvious areas for economies of scale, and Ukrainian enterprises are no exception. In addition, our research has shown that, despite the advantages of a business network, network enterprises also have that limit of achieving maximum efficiency, after which the scale effect is no longer observed. This made it possible to assert the reliability of the scientific hypothesis $\mathrm{H} 1$.

The positive economies of scale are associated with the effect of synergies in in-network enterprises. Sharing resources increases the value of each of them - the factors of production "help" each other. In addition, this effect is explained by savings on total production costs, such as administrative costs, sales promotion costs, and innovation costs. In non-networked enterprises, economies of scale are manifested as a rule due to their own strategic capabilities; that is, the achievement of a positive effect due to the complementarity of all the organization's competitive strategies at all levels. But the results of this empirical study have shown that the final indicators of economies of scale for both network and non-networked firms are characterized by relatively the same dynamics of development only at the stages of a positive 
development of organizations. But intense situations and (or) in times of economic downturn, synergistic firms are more resilient and perform better (economies of scale) than conventional companies, which, in turn, confirms hypothesis H3. The limitation of the manifestation of economies of scale and its negative significance is manifested where there is insufficient coordination of resources. The proper organization does not provide new additional resources. They, therefore, are less used, which is more typical for non-network enterprises at the stage of recession in their development life cycle.

The key factor in ensuring economies of scale for network enterprises is the strategic factor of managerial capabilities - the achievement of effect through the special competence of the organization's management - which, when integrated, pays significant attention to effective interaction between enterprises of the entrepreneurial network and between various departments within the enterprise. That is, in the context of business networkization, there is a transition from the principle of economies of scale in industrial enterprises to a broader principle of strategic economies of scale, the source of which is the mutual support of various network partners which ensures the achievement of a synergistic effect. The results obtained allow us to assert the reliability of the scientific hypothesis H2. At all stages of the life cycle, the synergistic effect of network interaction of industrial enterprises arises due to marketing advantages: access to new sales markets and the development of competitive potential, and at the stages of maturity and decline (also due to the concentration of intangible resources): rights to use natural resources, property, industrial property, copyright, and related rights.

The growth of sources of self-financing and borrowed funds has a positive effect on scale, regardless of the participation of enterprises in network structures, and it does not create additional synergistic effects from networking.

According to all indicators-sources of synergetic effect, the values at which profitability is maximized are higher relative to non-network enterprises for partners of network associations at all stages of the life cycle. The economies of scale for network partners are longer than the economies of scale in the normal business environment, confirming hypothesis H4. At the same time, within the framework of this hypothesis, the long-term nature is understood not as a time period but as the growth potential of indicators that create a positive synergistic effect. The time range was not assessed because the functioning of the enterprise over time may not be accompanied by the increase in resources and the use of network benefits. Under such conditions, a positive synergistic effect from network interaction is not created.

Within the framework of our study, the assessment of the synergetic effect for network enterprises was carried out based only on economies of scale. This is because the synergistic effect is a complex value and includes various types of synergy: investment effect, operational synergy, management synergy, etc. This, in turn, requires a more comprehensive and large-scale study, which does not allow reflecting the depth of the results within the framework of one article. In addition, today in Ukraine the development of business networks is at the initial stage of development, and the synergistic effect is achieved mainly due to economies of scale. But these aspects will be studied by us in further scientific research. In addition, it should be noted that the results obtained can only be applied to Ukrainian enterprises because the sample of enterprises for analysis is limited to one country and one industry.

\section{REFERENCES}

Akerlof, R., \& Holden, R. (2019). Capital Assembly. The Journal of Law, Economics, and Organization, 35, 3, 489-512. https://doi.org/10.1093/jleo/ewz012.

Andriuškevičius, K., \& Štreimikienè, D. (2021). Developments and Trends of Mergers and Acquisitions in the Energy Industry. Energies, 14, 2158. https://doi.org/10.3390/en14082158

Canbäck, S., Samouel, P., \& Price, D. (2006). Do Diseconomies of Scale Impact Firm Size and Performance? A Theoretical and Empirical Overview. The ICFAI Journal of Managerial 
Economics. III.

Chen, Z., \& Huang, L. (2019). Application review of LCA (Life Cycle Assessment) in circular economy: From the perspective of PSS (Product Service System). Procedia CIRP, 83, 210-217.

https://doi.org/10.1016/j.procir.2019.04.141

Cygler, J., \& Sroka, W. (2014). Structural pathologies in inter-organizational networks and their consequences. Procedia Social and Behavioral Sciences, 110, 52-63

Determination of the Organizational Life Cycle Stages. (2021). https://docs.google.com/forms/d/16VtuCK1 5rrk1BOs4W_gP0o-

j1yb6yA2yXPFjMe_KbA/edit

Dykan, V., Pakharenko, O., Saienko, V., Skomorovskyi, A., \& Neskuba, T. (2021). Evaluating the efficiency of the synergistic effect in the business network. Journal of Eastern European and Central Asian Research (JEECAR), 8(1), 51-61. https://doi.org/10.15549/jeecar.v8i1.646

Feix, T. (2020). Synergy Management. In: Endto-End M\&A Process Design. Springer Gabler, Wiesbaden. https://doi.org/10.1007/978-3-658-302894_5

Feizabadi, J., \& Alibakhshi, S. (2021). Synergistic effect of cooperation and coordination to enhance the firm's supply chain adaptability and performance. Benchmarking. An International Journal. https://doi.org/10.1108/BIJ-11-2020-0589

Gupta, I., Mishra, N., \& Tripathy, N. (2021). The Impact of Merger and Acquisition on Value Creation: An Empirical Evidence. The Importance of New Technologies and Entrepreneurship in Business Development: In the Context of Economic Diversity in Developing Countries, 194, 1435-1456. https://doi.org/10.1007/978-3-030-692216_107

Hsu-Ming, S., Kung-Jen, T., \& Ting-Yi, C. (2021). Establish a customer property service strategy framework. International Journal of Strategic Property Management, 25, 2042015.

https://doi.org/10.3846/ijspm.2021.14568

Jenkins, D.G., \& Quintana-Ascencio, P.F. (2020).
A solution to minimum sample size for regressions. PLoS One, 15, e0229345. https://doi.org/10.1371/journal.pone.02293 45.

Kim, S. (2014). Influence of Firm and Partner Resources on Firm Performance in the Alliance Portfolio. M@n@gement, 2(2), 88109. https://doi.org/10.3917/mana.172.0088

Kozan, M.K., \& Akdeniz, L. (2014). Role of Strong versus Weak Networks in Small Business Growth in an Emerging Economy. Administrative Sciences, 4(1), 35-50. https://doi.org/10.3390/admsci4010035

Kruja-Demneri, A. (2020). Entrepreneurial Orientation, Synergy and Firm Performance in the Agribusiness Context: An Emerging Market Economy Perspective. Central European Business Review, 9(1), 56-75. https://doi.org/10.18267/j.cebr.229

Megits, N., Neskorodieva, I., \& Schuster, J. (2020). Impact assessment of the COVID-19 on trade between Eastern Europe and China. Journal of Eastern European and Central Asian Research (JEECAR), 7(3), 385-399. https://doi.org/10.15549/jeecar.v7i3.579

Neskorodeva, I., \& Pustovgar, S. (2015). An Approach to Predicting the Insolvency of Ukrainian Steel Enterprises Based on Financial Potential. Journal of Eastern European and Central Asian Research (JEECAR), 2(2), 11. https://doi.org/10.15549/jeecar.v2i2.104

Problems of small and medium business: expert opinion. (2020, February 12). EconomistUA. https://economistua.com/problemi-malogota-serednogo-biznesu-poglyad-eksperta/

Rajagopal. (2014) Innovations, Technology, and Economies of Scale. In: Architecting Enterprise. Palgrave Macmillan, London, 174199.

https://doi.org/10.1057/9781137366788_7

Rodríguez-Villalobos, M., \& García-Martínez, J. (2018). Economies of Scale and Minimization of the Cost: Evidence from a Manufacturing Company. Journal of Eastern Europe Research in Business and Economics, 1-16. https://doi.org/10.5171/2018.128823.

Schmidt, J., Makadok, R., \& Keil, T. (2016). Customer-specific synergies and market convergence. Strategic Management Journal, 
37(5), 870-895.

https://doi.org/10.1002/smj.2372

Shi, H.-B., Cui, Y.-C., Tsai, S.-B., \& Wang, D.-M. (2018). The Impact of TechnicalNontechnical Factors Synergy on Innovation Performance: The Moderating Effect of Talent Flow. Sustainability, 10, 693. https://doi.org/10.3390/su10030693

The Commercial Code of Ukraine. (2021). Code on January 16, 2003 № 436-IV. Revision on June 13, 2021. https://zakon.rada.gov.ua/laws/show/43615?lang=en\#Text

Trunina, A., \& Ashourizadeh, S. (2021). Business model-network interactions: Comparative case studies from Zhongguancun and Silicon Valley. Technology in Society, 65, 101600. https://doi.org/10.1016/j.techsoc.2021.1016 00

World Bank Group. (2021). Ease of Doing Business rankings. https://www.doingbusiness.org/en/rankings

Zadorozhna, L. (2014). Forming Agroindustries Clusters for Reaching Competitiveness of Ukrainian Agroindustrial Sector. Journal of Eastern European and Central Asian Research (JEECAR), 1(1), 11. https://doi.org/10.15549/jeecar.v1i1.26

Zarte, M., Pechmann, A., \& Nunes, I.L. (2019). Decision support systems for sustainable manufacturing surrounding the product and production life cycle - A literature review. Journal of Cleaner Production, 219, 336-349. https://doi.org/10.1016/j.jclepro.2019.02.092

\section{ABOUT THE AUTHORS}

Alona Hrebennikova, email: aagrebennikova@gmail.com

Alona Hrebennikova, Ph.D. in Economics, National University of Life and Environmental Sciences of Ukraine, Kyiv, Ukraine.

Liudmyla Artemchuk, Ph.D. in Pedagogic Sciences, National University of Life and Environmental Sciences of Ukraine, Kyiv, Ukraine.

Vitalii Nahornyi, Ph.D. in Economics, National University of Life and Environmental Sciences of Ukraine, Kyiv, Ukraine.

Nadiia Daliak, Ph.D. in Economics, IvanoFrankivsk National Technical Oil and Gas University, Ivano-Frankivsk, Ukraine.

Olha Ruban, Ph.D. in Economics, National University of Life and Environmental Sciences of Ukraine, Kyiv, Ukraine. 